\title{
The Learning Model of Islamic Education in Al-Ihsan Integrated Islamic Basic Schools (SDIT) Pasuruan
}

\author{
Siti Yumnah
}

(Sekolah Tinggi Agama Islam (STAI) PAncawahana, Jl. Untung Surapati No.366, Bangil) sitiyumnah30@gmail.com

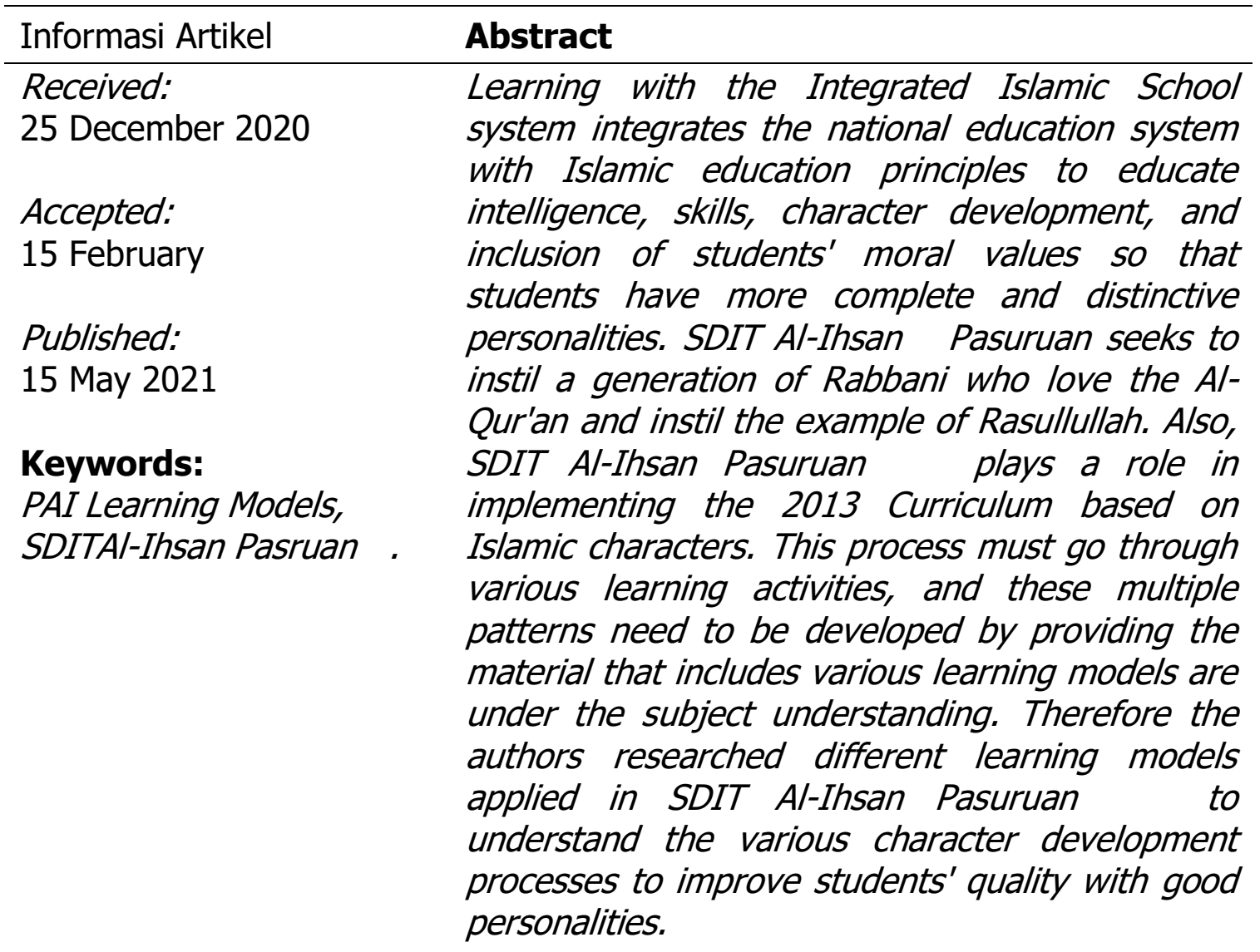

\section{INTRODUCTION}

Education is the centre of civilization for a nation in determining its progress and success in realizing the quality of reliable human resources. Also, education can improve a better standard of life, both for individuals and families in particular and the nation and state in general. The State of Indonesia should be both an Asian tiger and a superpower that successfully manages education, especially Islamic education (Purwanto, 2011). 
However, it is miserable that until now, Islamic religious education is still marginalized. Many Muslim intellectual leaders have provided advice on fixing the tangled threads of Islamic religious education, which can be used as an essential foothold in reconstructing education in Indonesia, one of which is AlSyaibani. He said that the implementation of Islamic religious education should emphasize improving morals, not only from the dominant intellectual side or becoming the competency standard (Nizar, 2011).

Likewise, Abduh, the modernist figure from Egypt who stated almost the same as al-Syaibani, that quality education can develop all the potential of students, especially the potential for knowledge and morals. That way, their thinking power will develop rationally by balancing the possibility of their intellect and the case of their religion. It will be planted in them the seeds of virtue that involve all their routine. From here, the writer can draw conclusions from the two figures' opinions that Islamic religious education for now should focus more on broa aspects by prioritizing all the ability,s of students, both in terms of psychological, social, as well as intellectual and spiritual, which are proportionate to various kinds of presentation. kinds of knowledge that are in tune with the progress and developmenKindsthe times. Thus, Islamic religious education becomes a facility in achieving a balance between students' intelligence and character to have broad knowledge and noble morals (Anwar, 2021).

Currently, many parents want to place their children in Islamic-based schools that can combine science and Islamic religious knowledge. Places or institutions that implement comprehensive Islamic religious education include integrated Islamic-based schools such as SDIT Al-Ihsan Pasuruan. The presence of SDIT Al-Ihsan Pasuruan provides an alternative solution for education and more modern school models. Therefore, the Integrated Islamic School provides good knowledge for their children who want to get guidance and quality education and quality (Ikhwan, 2014). 
The learning system in the Integrated Islamic School is a form of integration between the national education system and the Islamic education system based on principles that are built to educate their intelligence, skills, and build character and preserve the moral values of students, so that a complete and distinctive personality can be manifested in learners themselves. In learning, it can usually provide benefits, namely reinforcing the faith of monotheism and devotion specifically for the ideology of religion so that good education can combine the values of knowledge and spiritual values. With that purpose, it is none other than that students have an intact personality spirit, which can combine the knowledge they control with the values they believe in to overcome the various kinds of life problems in every aspect of human life.

SDIT Al-Ihsan Pasuruan is one of the schools that many people are interested in. The community assumed that placing their children in SDIT AlIhsan Pasuruan meant that they would get two benefits at once, namely achievement in general subjects and achievement in the religious field.

The Learning Model at SDIT Al-Ihsan Pasuruan is a form of planting Islamic teachings in the daily lives of students, both fardhu and Sunnah, such as establishing fardhu prayers in congregation, having memorized three chapters of the Qur'an with Tartil, having memorized the hadith of Arba'in Nawawi, Has learned daily prayers, mastered the International Language (Arabic-English), and many other social and educational activities of Islam. What is more, emphasized in Islamic Religious Education's learning pattern in integrated Islamic schools is to use the internalization method of Islamic religious education, namely through the application or practice of Islamic teachings.

\section{METHOD}

In writing this article, the author uses a qualitative research approach. This approach can be an approach to describe and analyse phenomena, events, and social activities, both individually and in groups (Syaodih, 2014). According 
to Sugiyono, qualitative research is usually referred to as ethnographic methods, phenomenological methods, or impressionistic methods. Meanwhile, in terms of data, qualitative research uses data that contains or is in the form of words, sentences, schemes, charts, and pictures (Sugiyono, 2015).

On the other hand, Lexy defines qualitative research methods as methods that have the characteristics of the natural environment (natural setting) as a direct, descriptive data source, a process that is more important than results, analysis in qualitative research tends to be carried out by inductive study and meaning is essential (Meleong, 2002). In terms of the type of research, the author uses the kind of case study, which describes and explains broadly various aspects of an individual, a group, an organization (community), a program or social situation, case study researchers try to examine as much data as possible about the subject under study, including research on the PAI learning model at SD IT Al-Ihsan Pasurusn (Mulyana, 2004).

SDIT Al-Ihsan Pasuruan is an elementary school located between Pasuruan and Pasuruan Regency's borders, more precisely on Jalan HOS Cokroaminoto No.5 Blandongan, Bugulkidul District, Pasuruan. It is a favourite elementary school for the people of Pasuruan and other areas.

SD IT Al-Ihsan is a school that can combine the national education system with the principles of Islamic education. Later, it is hoped that students can become human beings who are ready to answer the challenges of the times and can provide many benefits to society.

At SD IT Al-Ihsan itself, in addition to students being taught about the basics of education, students are also trained to be skilled and proficient in reading al-Qur'an. Also, students are accustomed to praying. They will have the awareness to establish prayers so that later there will be young, qualified, superior, and Islamic generations who can compete both academically and nonacademically who promote moral values and social interaction. Good.

The flagship programs implemented at the Al-Ihsan Integrated Islamic Elementary School in Pasuruan are: 
1. The program of tahfidz juz amma and memorization of 3 juz Al-Qur'an

2. Carry out the dhuha prayer in congregation

3. Memorize hadith Arba'in An-Nawawiyah

4. Dzuhur prayer activity program in congregation at the mosque

5. Memorize daily prayers.

6. International Language Course (Arabic-English).

7. Courses to apply Ms Word, Excel, and PowerPoint.

\section{FINDINGS AND DISCUSSION}

\section{Get to know the Learning Model}

In learning about the discussion of models, terms that have similarities in meaning are often used to confuse many people about understanding and differentiating them. The times are first, learning methods, second, learning strategies, third, teaching approaches, fourth, models learning, and the fifth, learning techniques. From these terms, the author will explain these terms to provide understanding and differences in the use of these terms.

1. The learning method is a method used to carry out a plan that has been designed in the form of concrete and practical activities to achieve learning objectives (Senjaya, 2008). Here are several kinds of learning methods that can be used to implement learning strategies: First, lectures, second, discussion, third, question and answer, fourth, practice, fifth, laboratory, sixth, field experience, and others.

2. Strategies or what is usually called learning techniques are a person's way of doing and implementing a method specifically to achieve the desired learning target (Hamdani, 2011). From this, we can see that there is a kind of different perspective in defining learning strategies.

3. The learning approach is a starting point in looking at a learning process that refers to a general process's perspective. Namely, there is a function providing a platform, giving inspiration, giving strength, and providing learning methods by harmonizing with specific theories. There are two 
kinds of approaches that can be used in the learning process, namely: First, learning techniques that lead or are student-centred, and Second, learning systems that show or are teacher-centred. As for examples of teaching approaches that show and are student-centred, such as thematic approaches (integrated), contextual (according to their content), collaborative (collaboration/duet), communicative (interacting with each other) and others (Trianto, 2007).

4. The learning model is a learning process practised directly by the teacher through group discussions presented from the beginning to the end of the lesson. Ibrahim, namely learning patterns packaged by applying an approach, strategy, method, and learning technique (Ibrahim, 2000: 2).

5. Learning techniques are planning in the learning process by using various potentials and using available facilities to increase learning effectiveness and efficiency. Thus, learning techniques are used to achieve optimal learning outcomes (Ibrahim, 2014).

In learning activities, there must be two human learners, namely, a teacher and a student. The teacher's behaviour is called a teacher, and the student's behaviour is called a learner. Both of these behaviours also have something to do with learning material. Learning material can also be in knowledge, attitudes, skills, religion, and values. -a value of decency. From the research results by education experts, teachers and students' interaction in learning is called a learning model (Rusman, 2011).

Teachers and students carry out activities using a learning model when interacting in the classroom, which is interpreted as influencing students' emotions, knowledge, and spirituality to encourage them to learn independently. Then later, there will be a development process of religious, moral values, activeness, and creativity of students through interaction patterns and learning skills. In principle, learning is very different from teaching. If teaching is more identical to teacher activities, education is more exact to student activities (Nata, 2009). 
On the other hand, while learning is a two-way communication pattern, teaching activities carried out by teachers are referred to as educators. Meanwhile, the learning activities are carried out by students. The goal in the learning process by the teacher is to build and develop students 'creativity to be able to increase the competence they have, both in terms of students' intellectuals and to be able to improve competence in finding new things about knowledge as an effort to stabilize learning material to be mastered (Sagala, 2010).

Joyce and Weli said that the learning model is the planning of content components in the curriculum formed as a goal and results of short-term and long-term plans in learning, such as designing learning materials and guiding and evaluating knowledge in class and others. In applying various learning models, teachers are given the freedom to choose and use the desired learning model that is considered appropriate and efficient in achieving educational goals.

\section{Innovation of Islamic Education Learning Model}

The discourse on innovation or renewal in Islamic Education learning in schools and madrasahs is a good form of endeavour in improving the learning system that is leading to a better and most different direction from previously programmed. This innovation, when viewed from a technological context point of view, leads to use and utilization. Technology functionally, whether application technology based on software or application technology based on hardware to support learning optimally (Sa'ud, 2014). The application of this renewable technology, the main objective is to upgrade the quality, effectiveness, and efficiency of learning. Innovation in education is not only in the form of technology. Still, it is also needed in terms of the ability of a teacher in the field of mastery of methods and strategies that have been innovated, so that the message of Islamic Education learning contained in the Koran and Hadith can be understood clearly and in terms of the learning system will also experience significant progress. 
Many experts are currently able to create Islamic software applications that can be used and utilized to support learning, for example, PowerPoint applications, adobe flash, Powtoon, adobe premiere, al-Qur'an and digital hadiths Islamic e-books and others. So in using this tool, it is hoped that it will have a positive impact on the world of education, including in Islamic Education learning. By utilizing it, learning will be easier to channel; students will not feel quickly bored, let alone not fixated on just one method. So that there are no longer considered PAI teachers to be clueless or outdated.

\section{Problem Based Learning Model (PBM)}

This learning model, or what we often hear from its foreign term ProblemBased Learning. This learning model has long been famous since the time of John Dewey. Until now, this learning model was raised again to be studied again so that students can encourage seriousness in thinking in a meaningful and meaningful way. Very strong. So that later it will make it easier for students to investigate the problem that occurs (Afandi, 2013).

On the other hand, in Bound and Felleti's view, problem-based learning is the most incredible innovation and renewal in education. Because in the curriculum itself, the Problem Based Learning model can help develop student learning skills throughout life and make their mindset more open, reflective, critical, and active learning.

\section{Contextual Learning Model}

Contextual Learning, or what is commonly called Contextual Teaching and Learning, is a learning concept that focuses on the relationship between subject matter material and real-life situations and conditions of students to relate and apply their abilities in daily activities (Ngalimun, 2014).

Therefore, through this learning model, learning does not form knowledge that can be transmitted from the teacher to students by memorizing various concepts, for example, from experiences in real life, but what is more focused is the effort to provide all the needs of students to find talent and potential to be able to live independently in learning. Therefore, knowledge will be significant if 
the school is very closely related to the community, but in its function, what is learned in school is always in direct contact with the conditions and problems of life in the surrounding environment.

\section{Cooperative Learning Model}

This learning model, or what we usually call the name operative learning. In essence, it is a learning pattern that teaches students how to learn and work together in a small community in collaboration with members consisting of about 4-6 people with varied group compositions (Ikhwan, Noh, \& Iman, 2020). Meanwhile, according to Nurul Hayati, cooperative learning can be interpreted as a learning strategy that involves students' participation in a small group to communicate with each other.

Cooperative learning is different from the group learning method. There are essential elements of collaborative learning that differentiate it from random group learning. Correct implementation of the joint learning system's basic principles will enable teachers to manage the classroom more effectively. Cooperative learning in the learning process does not have to learn from teachers to students. Students can teach each other fellow students.

\section{PAI Learning Model at SDIT Al-Ihsan Pasuruan}

A learning model is a form of learning that describes teaching and learning activities from beginning to end. The learning model is an outline of the overall strategy, approach, method and learning technique. The implementation of the approaches, strategies, methods, techniques and even learning tactics that have been strung together into a unified whole is what forms a learning model. Based on interviews, observations, literature and documents in SDIT Al-Ihsan, Pasuruan. SDIT Al-Ihsan Pasuruan, applies various learning models in the implementation of Islamic Religious Education learning, including the following:

\section{Learning Approach SD IT Al-Ihsan Pasuruan}

In its implementation, SD IT Al-Ihsan, Pasuruan applies two learning approaches: a student-centred learning approach and a teacher-centred approach to learning. These two approaches are used in grades IV and V. The 
division of a teacher's roles to students is carried out in discussion sessions and question and answer during each group's presentation.

Both of these approaches are very suitable to be applied to Islamic Religious Education learning. The various material discussions covered in it can encourage students to think critically and express opinions that students can experience through their daily lives.

A student-centred learning approach and a teacher-centred learning approach in a balanced manner can provide a more profound understanding. Both of these approaches are also by a large number of students in SD IT AlIhsan Pasuruan .

This can be seen in the author making observations in grade IV when the teacher explains the sub-subject matter related to Akhlaqul Karimah with a fondness for reading. When a picture illustration is displayed related to reading activities, the teacher asks students to comment on an image that they have observed earlier. The teacher's task is to explain what he has told the students about their results. Observe.

In each subject matter about Akhlaqul Karimah, one student tends to pay less attention and respect to his friend when submitting an opinion. The teacher takes the initiative to implement the activity of analyzing images so that students can focus their attention on giving their arguments. This can stimulate engagement so that they always focus on paying attention to the lesson. So it can be said that this approach is efficient to be used to provide opportunities for students who want to understand the Akhlaqul Karimah material fully.

\section{Learning Strategies SD IT Al-Ihsan, Pasuruan}

A teacher will certainly try to create a good and comfortable learning climate. One of them is implementing learning strategies that are most likely to assist in the learning process and help achieve the learning objectives that have been formulated $(S, 2015)$. With this learning strategy, it is hoped that it can become a reference and measure for professional teachers because the learning process is a process of interaction between students, teachers, and the 
learning environment. Therefore, this learning strategy can be used as a reference in acting in an orderly and orderly manner in implementing learning to understand the material quickly.

According to the results of the field carried out through observations, structured interviews and documents in the form of lesson plans, the syllabus of class IV and $\mathrm{V}$ teachers at SDIT Al-Ihsan Pasuruan, have applied various learning strategies that can support the effectiveness of Islamic Religious Education subjects, one of which is:

a. Expository learning strategies

An expository learning strategy is a form of teacher-oriented learning approach because it plays a dominant role. This strategy includes lectures and questions and answers. The teacher actively provides stimulation to students to find and observe everyday life events by the material being studied. The fifthgrade learning process's initial activity is where the teacher instils a religious attitude, is polite, and thinks logically. asking the question, "What do we do if our friends need help?" students answered aloud "help, sir!". "Yes, that's right, we have to help, but what do you do when you need help, and the friend doesn't help?" The student responded with the answer "a little angry, sir", "Well, if you are angry, it means when you help it. not sincere, is not being sincere is good?", "not good sir "the student replied. The teacher then explained the sincere attitude of charity and simple life taught by Rasulullah SAW and presented the material to be discussed.

In this learning activity, the teacher becomes the centre of attention for students in explaining a sincere attitude of charity and a simple life. The author tries to interview Mr Achmad Fuadi S.Pd.I, as an Islamic religious teacher. He explains that the learning strategy uses the method lectures do need to be done in conditioning the class to be calmer. Said Mr Achmad Fauzit. It turns out that discussion activities using the presentation model are considered quite effective because students feel more focused and pay more attention to the teacher's direction and guidance. 


\section{b. Inquiry Learning Strategies}

Inquiry learning strategies are learning activities that emphasize thinking critically and analytically to seek definite answers to the problem. Inquiry learning strategies emphasize mental processes and thought processes by optimally utilizing each individual's potential.

In practice, the student-centred inquiry strategy. PAI learning at SDIT AlIhsan Pasuruan also implements this strategy. This is carried out during the core activity where it asks students to go forward and demonstrate the reading of QS Al-Furqan verse 67 and its meaning which all students follow. Then the class was divided into several groups and discussed QS Al-Furqon verse 67 and QS al-Isra verse 27, which contains simple life and prohibitions on being extravagant or mubadzir. Each group is asked to discuss and then present the results in front of the class. After each group finishes giving a conclusion, the teacher as the mediator provides reinforcement and explains again about the application of simple life.

\section{c. Contextual Learning Strategies}

Contextual learning strategies are a conception that helps teachers relate subject content to real-world situations and motivates students to make connections between knowledge and its application in their lives as family members, citizens, and the workforce. Contextual learning strategies are a learning concept that assumes that children will learn better if the environment is created naturally, work and experience what they learn, not just knowing.

Mrs Lailatul Fitriyah uses this strategy to deliver learning material about ulul azmi. She tells various stories about ulul azmi and role models related to an unyielding attitude. She allows asking questions about their never-giving up mentality, which is followed by randomly selecting students. Who will be appointed to answer questions from other students. Then implement and ask about students' experiences regarding never giving up. Students are asked to give examples of never-giving up attitudes and discuss and conclude some attitudes that reflect an unyielding attitude in life with their group. 


\section{d. Contextual Learning Strategies}

Contextual learning strategies are a conception that helps teachers relate subject content to real-world situations and motivates students to make connections between knowledge and its application in their lives as family members, citizens, and the workforce. Contextual learning strategies are a learning concept that assumes that children will learn better if the environment is created naturally, work and experience what they learn, not just knowing.

Mrs Lailatul Fitriyah uses this strategy to deliver learning material about ulul azmi. She tells various stories about ulul azmi and role models related to an unyielding attitude that allows students to ask questions about their nevergiving up mentality, followed by randomly selecting students. Who will be appointed to answer questions from other students. Then implement and ask about students' experiences regarding never giving up. Students are asked to give examples of never-giving up attitudes and discuss and conclude some attitudes that reflect an unyielding attitude in life with their group.

\section{Learning Methods of SD IT Al-Ihsan, Pasuruan}

The method is the teacher's method to include one of the educational interactions. The learning method can be interpreted as the teacher's method in establishing relationships with students during the chase. Thus, the learning method is a tool for creating a teaching and learning process.

The learning method is also assumed to be a learning technique. Rumiyati explained that the learning method could be interpreted as a method used to implement plans that have been prepared in the form of fundamental and practical activities to achieve learning objectives. Several learning methods can be used to implement learning methods, including lectures, demonstrations, discussions, simulations, field experiences, brainstorming, debates, etc. SD IT Al-Ihsan, Pasuruan , applies several methods arranged in the RPP by the material to be studied. The learning methods implemented at SD IT Al-Ihsan, Pasuruan, are lectures, question and answer, discussion, demonstrations, assignments and problem-solving. 


\section{Learning Media SD IT Al-Ihsan Pasuruan}

Learning media in the current digitalization era can be a powerful tool in stimulating students to encourage their enthusiasm for learning. As stated by Wina Sanjaya, learning media includes hardware that can distribute messages and software. Containing the message content. Media is not only a tool or material but also other things that allow students to gain knowledge. (Sanjaya, 2008: 35). And also, media is not only in electronic devices such as television, radio, computers but also includes human elements as a learning source or learning information source. This can be obtained when conducting discussions or seminars, simulations, and so on. Rather than learning, media can distribute messages, stimulate thoughts, feelings (conscience), and encourage students to create an independent learning process. As for PAI learning media used in learning at SD IT Al-Ihsan, Pasuruan, include:

a. Sources of material or something used to pack learning messages can be obtained through textbooks, student worksheets, props, films, slides, and so on.

b. Immaterial sources or something experiential or based on information from events such as cases, stories, legends, culture, etc.

c. Conditional sources or environments inside the school or outside the school, whether deliberately designed for the learning process or not, such as classrooms, studios, libraries, halls, mosques, etc.

d. Personal sources or people who store information. Because basically, everyone can act as a professional learning resource, such as teachers, school principals, educational instructors, counsellors, and others.

The author concludes that implementing the learning process in the classroom. If there are no learning media that cannot support student success in learning, students will find it difficult to understand a learning material. With the help of the media, especially in implementing Islamic Education learning media, it is not only limited to material sources, but it is also necessary to use 
immaterial sources, conditional sources, and private sources so that they can be used together to improve the quality of Islamic Education learning.

\section{CONCLUSION}

On average, almost all teachers or educators at SD IT Al-Ihsan Pasuruan, in carrying out Islamic religious education lessons, have applied a heterogeneous learning model in line with the subject matter being taught. There are already several learning strategies in the learning model, including cooperative, expository, inquiry, and contextual learning. To realize the vision and mission of the school which wants the formation of Islamic character in students, at SD IT Al-Ihsan, Pasuruan also implements various kinds of activities to support the creation of a religious learning climate such as dhuha prayer activities in the congregation, reading and memorizing short letters for all students, following Arbain Nawawi's hadith book studies, and participating in Arabic and English language training activities.

\section{BIBLIOGRAPHY}

[1] Afandi, M. (2013). Model Dan Metode Pembelajaran Di Sekolah. Semarang: Sultan Agung Press.

[2] Anwar, S. (2021). Internalisasi Nilai Pendidikan Akhlak dalam Surat AlHujurat Tafsir fi ZIlalil Qur'an. JIE: Journal of Islamic Edication, 6(1), 112.

[3] Hamdani. (2011). Strategi Belajar Mengajar. Bandung: Pustaka Setia.

[4] Ibrahim, M. (2014). Pembelajaran Kooperatif. Surabaya: University Press.

[5] Ikhwan, A. (2014). Integrasi Pendidikan Islam (Nilai-Nilai Islami dalam Pembelajaran). Ta'allum: Jurnal Pendidikan Islam. https://doi.org/10.21274/taalum.2014.2.2.179-194

[6] Ikhwan, A., Noh, M. A. C., \& Iman, N. (2020). IMPLEMENTATION OF THE TAHFIDZAL-QUR'AN CURRICULUMAT THE TAHFIDZ MALAYSIA BOARDING SCHOOL. Journal of Critical Reviews, 78$), 866-870$.

[7] Meleong, L. (2002). Metodologi Penelitian Kualitatif. Bandung: PT Rosda Karya. 
[8] Mulyana, D. (2004). Metodologi Penelitian Kualitatif. Bandung: PT Remaja Rosdakarya.

[9] Nata, A. (2009). Perspektif Islam tentang Strategi Pembelajaran. Jakarta: Kencana.

[10] Ngalimun. (2014). Strategi Dan Model Pembelajaran. Yogyakarta: Aswaja Pressindo.

[11] Nizar, S. (2011). Sejarah Pendidikan Islam: Menelusuri Jejak Sejarah Pendidikan era Rasulullah sampai Indonesia. Jakarta: Kencana.

[12] Purwanto, M. N. (2011). Ilmu Pendidikan Teoritis Dan Praktis. Bandung: Remaja Rosdakarya Offset.

[13] Rusman. (2011). Model-Model Pembelajaran Mengembangkan Profesional Guru. Jakarta: Rajawali Pers.

[14] S, S. (2015). Strategi Pembelajaran Pendidikan Agama Islam Antisipasi Krisis Akhlak Peserta Didik Pada Sma Negeri Di Palopo. INFERENSI: Jurnal Penelitian Sosial Keagamaan, 9(2), 377.

[15] Sa'ud, U. S. (2014). Inovasi Pendidikan. Bandung: Alfabeta.

[16] Sagala, S. (2010). Konsep dan Makna Pembelajaran. Bandung: Alfabeta.

[17] Senjaya, W. (2008). Strategi Pembelajaran: Berorientasi Standar Proses Pendidikan. Jakarta: Kencana Prenada Media Group.

[18] Sugiyono. (2015). Metode Penelitian dan Pengembangan Pendekatan Kualitatif, Kuantitatif, dan R\&D. Metode Penelitian dan Pengembangan Pendekatan Kualitatif, Kuantitatif, dan R\&D.

[19] Syaodih, N. (2014). Penelitian Deskriptif Kualitatif.

[20] Trianto. (2007). Model Pembelajaran Terpadu Dalam Teori dan Praktek. Jakarta: Prestasi Pustaka. 